\title{
Promoting Innovative and Entrepreneurial Talent Cultivation in Cameroon Higher Education: Significance, Challenges and Opportunities
}

\author{
Jean Patrick Mve \\ College of Teacher Education, Zhejiang Normal University \\ 688 Yingbin Avenue, Jinhua, Zhejiang Province 321004, China
}

\begin{abstract}
Many African countries are involved in the implementation of numerous strategic programs to achieve national emergence and development. These efforts are encountering many difficulties, especially in terms of the availability of higher-skilled human resources. Cameroon, a Sub-Saharan African country, is not an exception to this situation in this group of countries. Cameroon is making tremendous development-related efforts but the shortage of an innovative workforce is superseding its social and economic growth. One of the core missions assigned to the country's higher education is to produce innovative and entrepreneurial individuals that are valuable assets to the effective development of the country. Based on available research and information, this study focuses on the issue of talent cultivation in Cameroon higher education. It investigates the significance of promoting the cultivation of innovative and entrepreneurial talents in the country's higher education. It further identifies the core challenges faced by the Cameroonian higher education concerning innovative and entrepreneurial talent cultivation. Lastly, it recommends some relevant strategies that involve boosting the cultivation of innovative and entrepreneurial talents in the country's higher education.
\end{abstract}

Keywords: talent cultivation, innovative and entrepreneurial talents, higher education, Cameroon

DOI: $10.7176 / \mathrm{JEP} / 11-35-08$

Publication date: December $31^{\text {st }} 2020$

\section{Introduction}

By 1962, there was a crucial need for trained human resources to occupy positions in the public service and government corporations in Cameroon as most Western administrative expatriates had to leave the country after the independence in the 1960s. Thus, Cameroon higher education, largely financed by the government, involved in the training and cultivation of an elite social class that would replace Western expatriates for administrative positions (Bella 2010; Njeuma et al. 1999). From the 1960s to the 1980s, Cameroon like many other African countries invested heavily in higher education to achieve the goal of cultivating qualified people for public service positions (Amin et al. 2005). The number of higher education learners was relatively low so that their training was consequently of good quality and university training and academic degrees automatically opened doors to the job market (Njeuma et al. 1999). During this period the country, therefore, registered tremendous economic growth and this period was therefore called the "20-year golden age" in Cameroon (Ntemngweh 2016). This golden age suddenly shifted into a black age from 1986 when a deep economic crisis started to hit the country. The World Bank and International Monetary Fund (IMF) Structural Adjustment Programs (SAP) were then imposed on the country, which has weakened the capacity of the then-largest source of employment, the public sector (Geo-JaJa et al. 2001) and decreased higher education funding. In addition to the national economic downturn, there has been a tremendous increase in enrolment in Cameroon higher education. In the absence of an adequate policy for higher education human, financial, and physical resources. The exponential growth of the student population led to the decline of higher education quality, resulting in the critical increase in the number of unskillful students graduating from the country's universities each year (Neneh 2014). As Cameroon wants to emerge by achieving a good level of economic and social development by 2035 (Republic of Cameroon 2015), it needs highly skilled human resources to accomplish such a vision and higher education's role is crucial for the cultivation of such innovative talents. Cameroon higher education has carried out many reforms to achieve the crucial goal of training highly skilled and creative graduates that are essential for the country's economic and social development. However, innovative and entrepreneurial talents are still very scarce within the country. Teneng (2016) investigated the quality of skills of higher education graduates in Cameroon and found that talent cultivation was very limited in Cameroonian universities (Teneng 2016). Therefore, it is worth examining issues related to talent cultivation in Cameroon higher education. In an attempt to promote the cultivation of innovative and entrepreneurial talents in higher education to boost national development, this paper seeks to answer the following questions: How significant is the issue of talent cultivation in (Cameroon) higher education? What are the core challenges faced by Cameroon higher education in the process of talent cultivation? What strategies are relevant to address such challenges? 


\section{The Concept of Talent (Cultivation)}

Talent can be defined as a natural resource that is detected, controlled, and enhanced. It involves an ability that is not observable or directly measurable but expressed through a skill or set of skills and is illustrated in success (Peretti 2009). Talent is also characterized by the use of a personal style that creates a difference in professional achievement. This personal style, according to Peretti (2009), results from the person's soft skills, his or her personality, while escaping any conventional form of normalization. Talent is therefore the excellence associated with a high evolution potential in a given activity as compared to others. The talented individual is thus an individual who develops excellence and originality (Peretti 2009). According to Miralles (2007) and Ulrich (2012), talent results from internal factors (spirit of innovation, innovative personality, innate abilities, motivation, passion, ambition, work, and constant efforts) but also from external factors necessary for its recognition and development (personal, academic, professional environments). They agree with Peretti (2009) that talent is the combination of excellence and difference (Miralles 2007; Ulrich et al. 2012). Analyzing the conceptualization and definition of the term "talent" in the Chinese cultural context, Zhang (2017) suggests that, like in Western contexts, "talent" refers to a person's special ability for doing something (Zhang 2017). Yang Chunqiao (2005) focuses on the basic quality that innovative talent should have. The author suggests that creative talents should be able to perform some intelligent quality, cultural quality, and health quality including the quality of innovation which refers to making new development, breakthroughs on the original basis (Yang 2005). Zhang (2017) introduced the concept of "valued talents" and suggested that talents should not be valued based on literacy and academic performance, but rather based on the ability to make innovative contributions to society (Zhang 2017). Talents cultivation, therefore, refers to the cultivation of individuals who develop excellence and the difference that lead to new ideas and new achievements. Cultivating innovative talents involves the training of people who develop the spirit of creativity and perform some intelligent quality. Cultivating innovative talents, therefore, appeals for (a) the accumulation of functional skills along with the cultivation of individuals' characters; (b) the simultaneous implementation of innovative and professional education; (c) the evaluation of students' skills while cultivation individual expertise; (d) the combination of teaching with practical innovation $(\mathrm{Wu}$ and $\mathrm{Zhu} 2017)$. Thus, the characteristics of innovative talents include the spirit of innovation, creativity, excellence, and innovative personality. Innovative talents are always good at breaking the routine and at identifying society's problems, analyzing such problems, and solving them (Guo 2000). Calling for the reform of (higher) education, Wu and Zhu (2017) suggest the implementation of a more innovative and entrepreneurial model of education that effectively boosts the innovative and entrepreneurial abilities of students. They define (innovative) talent cultivation as the training of individuals with the most innovative and entrepreneurial personalities. Innovative talents should possess a spirit of originality, risk-taking, entrepreneurship, and professional independence, as well as effective managerial skills (Wu and $\mathrm{Zhu}$ 2017). The mastering of existing knowledge is not enough for a society to develop and the cultivation of "outstanding creative talents" is crucial for a country's development (Zhang 2017). Zhang (2014) developed a competence model for the cultivation of talents with entrepreneurial skills, able to effectively contribute to the economic development in China. The author suggests that national economic development and industrialization require the cultivation of many talents with entrepreneurial skills that are considered as the backbone of any society. The author argues that colleges and universities have to adopt an advanced talent training model to cultivate a batch of entrepreneurial talents, with the necessary competence to meet the demands of society (Zhang 2014).

\section{The Significance of Talents Cultivation in Cameroon Higher Education}

\subsection{Achieving the 2035 Vision for an Emerging Cameroon}

The Cameroonian government has undertaken, in partnership with the civil society, the private sector, and development partners, the formulation of a long-term vision for the development of Cameroon. This operation signals a major qualitative reorientation in the economic history of the country over the last twenty years. In fact, before 1985, according to the Ministry of Economy, Planning and Land Planning (MINEPAT), Cameroon experienced two decades of steady growth: the Cameroonian economy recorded real growth rates of around $7 \%$. However, as early as 1985, Cameroon was severely hit by a major economic crisis that completely weakened its economy (MINEPAT 2009). In front of this crisis, the government of Cameroon has undertaken economic recovery measures and, with the support of the donors, carried out stabilization and structural adjustment programs that have enabled the country to regain the path of growth (Republic of Cameroon 2015). However, this growth has not reached a lasting vigor likely to reduce poverty in the near term. Cameroon, to reinforce this economic recovery and establish it sustainably, had to put its development policies back into a wider and more comprehensive perspective. Hence the need to have a foresight vision, prior to a national long-term development strategy. Following a participatory approach involving all the forces of the nation, the structural studies of the system, the aspirations of the Cameroonian people, and the international commitments subscribed by the government, a shared vision of Development in Cameroon emerged. The resulting vision has been retained as its main aim: to make Cameroon an emerging country by 2035. This aim relies on the following four fundamental objectives, according to MINEPAT (2009): 
a) Eradicating poverty, reducing it to less than $10 \%$;

b) Achieving the stage of the middle-income country;

c) Achieving the stage of New Industrialized Country; and

d) Achieving the stage of an emerging country, with the integration of Cameroon to the world economy through a great capacity of exports and the opening of the financial markets to the external capitals (MINEPAT 2009).

However, without qualified and highly skilled human resources, Cameroon will hardly achieve such an ambitious vision. Cameroon is a country with a large youth population that relies on a resource-dependent and import-dependent economic and social development regime. For instance, more than $60 \%$ of the Cameroonian population was under the age of 25 in 2017 (NIS 2017). Due to this large young population and the relatively less per capita resources, the high dependence on imports and resources can lead Cameroon into an inadequate capacity for sustainable development. However, this large youth population can also become a valuable asset for sustainable development if it is transformed into innovative entrepreneurial human resources. Higher education has the duty of training such highly skilled human resources.

The law of orientation of higher education proposed by the Ministry of Higher Education (MINESUP) and adopted in 2001, advocates that Cameroon higher education institutions should accompany the State in achieving its development objectives (MINESUP 2001). Hence, the cultivation of innovative talent can enhance Cameroon's export and scientific and technological innovation capacities and allow the country to effectively achieve its vision of becoming an emerging nation by 2035. In this regard, the Cameroonian government has tried to emphasize the issue of talent cultivation by reforming higher education programs and curricula since 2005 . This reform called the "LMD Reform" (Bachelor, Masters, and Doctorate Reform) appeals for higher education stakeholders to train highly skilled and qualified young people, who can both fit the requirements of the job market, innovate and create opportunities by themselves, and lead Cameroon to the achievement of the 2035 Vision. However, innovative and entrepreneurial talents are still very scarce within the country because higher education is not successful enough in this area (Teneng 2016). Being on this path of a future middle-income country by the 2030s, Cameroon needs highly skilled human resources that are crucial to achieving substantive growth and development. Higher Education can thus play a vital role in terms of talent cultivation. Since it is through the cultivation of innovative talents that higher education can show its value as far as the national economic and social development is concerned (Changli 2009). Teneng (2016) suggests that higher education institutions in the country should promote a more skill-orientated curriculum to produce highly skilled graduates; skill-oriented higher education curricula could become the safest route of escaping the unemployment trap and growing individual ability for innovative contribution to the country's development (Teneng 2016). Higher education must cultivate the innovative and entrepreneurial talents needed for the development of society. The cultivation of innovative talents in higher education institutions plays a crucial role not only in universities' and in personal development, but also in the country's economic and social development. There is no doubt that human capital cultivating is the essence of education, especially higher education (Changli 2009). Therefore, the issue of talent cultivation in higher education is of paramount significance in any national context where economic and social emergence and development are to be achieved.

\subsection{Unemployment and Education-Job Mismatch among University Graduates}

According to the International Labor Office (ILO), the unemployed are persons without work, who are currently available for work and are seeking work (ILO 1983). Unemployment is treated in this study essentially concerning the first professional insertion, which mostly affects the youths and higher education graduates (Amin et al. 2005; Ntemngweh 2016). The exponential growth of the student population in campuses has resulted in a critical increase in the number of graduates release to the job market each year without a corresponding increase in job creation to meet up the increased job demands (Neneh 2014). Many authors advocate that, in recent years, the higher graduation rates have also resulted in an increase in unemployment among graduates, especially graduates of public universities (Elias et al. 2004; Ekane 2010; Mbah 2014; Ntemngweh 2016). The unemployment rate seems to increase in Cameroon with the level of education (Cameroon Youths and Students Forum for Peace 2014). For instance, the overall estimated youth unemployment rate in Cameroon was at 8.86 percent in 2017. It is under 9\% for individuals with at most the secondary education level and $13 \%$ for those with higher education level (ILO 2017). Poor quality of educational provision is one of the core factors of graduates' unemployment. The phenomenon of unemployment is illustrated by low productivity and weak competitiveness within the country. Thus, Cameroon lags behind most countries in terms of competitiveness: the country is ranked 168 out of 189 economies in the world (Republic of Cameroon 2015). This situation is coupled with another phenomenon: (higher) education-job mismatch. Indeed, (higher) education-job mismatch is construed as being embedded in such a weak and stagnating economy that stifles job creation (Ntemngweh 2016). All these elements show that there is an acute need in the Cameroonian society that only higher education can meet: the cultivation of innovative talents that only can solve the problems of employability, productivity, and competitiveness (Teneng 2016). There is a need 
for creating more dynamic and responsive workforce skills, and a competencies development system to address potential new jobs and requirements in Cameroon. Higher education can make valuable contributions to developing skills, spurring growth, increasing competitiveness, and helping Cameroon evolve to higher-value products and services and achieve its socio-economic development. Skills and innovative and entrepreneurial spirit development is capable of driving employment and boosting productivity and development (Ansu et al. 2012). It is therefore the duty of Higher education in Cameroon to cultivate innovative talents to meet this need.

\section{Core Challenges of Talents Cultivation in Cameroon Higher Education}

Like in many other African countries, the process of innovative talents cultivation is facing serious challenges in higher education institutions in Cameroon. The current study focuses on major challenges faced by the Cameroonian higher education and that continue to hamper the enterprise of innovative talents cultivation in Cameroon. These include massification, shortage of funds, and the phenomenon of brain drain

\subsection{Massification}

From the very beginning of higher education in Cameroon in the 1960s, the government has adopted an open-door academic policy. Aimed at making post-secondary education accessible to everyone, the open-door policy was imposed on the majority of public universities, except the University of Buea, public professional and technical schools, and private institutions. So, the majority of public universities are obliged to enroll all students holding a terminal high school diploma (Fouda et al. 2012). This measure followed the United Nations requirements for education policy, whereby all citizens without exception, should have access to education at all levels (UNESCO 2000). Consequently, Cameroon higher education has experienced massive enrollments resulting in an extraordinary rampant massification as universities became severely and continuously over-crowded by students (Njeuma et al. 1999; Fouda et al. 2012). Table 1 depicts the evolution of the student population in higher education from 2005 to 2020 .

Table 1. Evolution of the student population of higher education from 2005 to 2020

\begin{tabular}{|l|l|l|l|l|l|}
\hline $\mathbf{2 0 0 5}$ & $\mathbf{2 0 1 0}$ & $\mathbf{2 0 1 1}$ & $\mathbf{2 0 1 2}$ & $\mathbf{2 0 1 3}$ & $\mathbf{2 0 1 4}$ \\
\hline $1,971,012$ & $2,330,080$ & $2,388,230$ & $2,447,325$ & $2,507,364$ & $2,568,350$ \\
\hline $\mathbf{2 0 1 5}$ & $\mathbf{2 0 1 6}$ & $\mathbf{2 0 1 7}$ & $\mathbf{2 0 1 8}$ & $\mathbf{2 0 1 9}$ & $\mathbf{2 0 2 0}$ \\
\hline $2,649,945$ & $2,713,288$ & $2,777,586$ & $2,842,835$ & $2,909,035$ & $2,998,272$ \\
\hline
\end{tabular}

Source: National Institute of Statistics, 2015 (Projections from Central Bureau of the Census and Population

Studies for the Years 2016-2020).

Table1 shows that the student population in Cameroon higher education is continuously increasing over the years. Indeed, school attendance in Cameroonian higher education institutions amounts to 1,971,012 students in 2005. In 2015, the number of students attending higher education in the country rose to 2,649,945. Moreover, the provisions made by the Central Bureau of the Census and Population Studies showed that the student population would rise to 2,998,272 in Cameroon's higher education institutions by 2020 (NIS 2015). This irreversible massification of higher education has resulted in high teacher-student ratios. For example, the Ministry of Higher Education (MOHE) has investigated the number of teachers and students from the existing higher education institutions in the country in 2018 and found that the teacher-student ratio was 1/52 (MINESUP, 2020). This is a result of rampant massification in this sector. Coupled with inadequate or insufficient physical resources, this rampant massification has negatively affected higher education quality among numerous tertiary education institutions in the country (Njeuma et al. 1999; Michaela 2012; Bilola et al. 2016). The overall situation is therefore hampering the process of talent cultivation in Cameroon higher education day after day.

\subsection{Shortage of Funds}

The Cameroonian society as a whole has experienced a black age from 1986 when the country was hard hit by a deep-seated economic crisis, with education being one of the most affected sectors. The crisis coupled with the implementation of neo-liberal policies such as Structural Adjustment Programs (SAP) of the World Bank and International Monetary Fund (IMF) affected the role of the largest source of employment- the public sector in most African countries including Cameroon (Geo-JaJa et al. 2001). In addition to this economic downturn, from the 1960s onwards, there has been a tremendous increase in enrolment in Cameroon higher education. This dramatic increase in student enrollment in higher education has not been matched with a corresponding policy on higher education's financial resources, especially in terms of governmental funding. The ongoing increase in higher education's student population requires the recruitment of more faculty and the building of additional infrastructures, as well as the maintenance of the existing physical resources. Yet, the availability of public funds is extremely limited. Though universities are encouraged to undertake incomes generating activities, their capacity to generate sufficient funds for their functioning is still critical (Ngwe 2016). Consequently, the State continues to provide the bulk of the costs. However, the degree and constancy of such funding are very precarious as the universities compete for scarce funds with other sectors that the State also finances. For example, one can observe 
a contraction in public funding of the whole education system between 2002 and 2011 as a percentage of government expenditures. It has increased from $27 \%$ in 2002 to less than $20 \%$ since 2007 and decreased to $16.5 \%$ in 2011. This corresponds to 3.2\% of GDP. More importantly, the percentage of the whole budget of the Cameroonian MOHE is $1.36 \%$ of the State budget, which is not enough to effectively support higher education institutions in talent cultivation activities. The RESEN (State Report on the National Education System) has shown that with such a level of funding, Cameroon is below the developing country average of $4.4 \% 6$. Given the results and progress to be made at all levels of the system to reach the level of development desired by Cameroon, public funding of education seems insufficient given the challenges of growth of the education system, especially tertiary education (Lahaye et al. 2013).

Apart from the State's financial support, Cameroonian institutions of higher education highly depend on school fees paid by students (Fouda et al. 2012). However, school fee is not considerable or high in public institutions as it is in private institutions. In fact, in order not to render access to the university difficult for students from a poor economic background, the higher education reform of 1993 introduced a token registration fee of 50,000 CFA Francs per student per annum (approximately \$85) after the reform of 1993. This fee is irrespective of the degree program or kind of degree pursued. This fee amount charged to students remains far below the fees paid by students even in the country's private primary and secondary schools (Njeuma et al. 1999). Thus, due to the shortage of funds, the growth in teaching staff numbers fails to keep pace with enrolments. Additionally, this has resulted in inadequate and insufficient physical resources on campuses. For instance, the available lecture rooms and theatres as well as laboratories, academic staff and administrative offices, and even sanitary facilities are grossly inadequate to meet the needs of the enlarged student population in Cameroonian universities. Most institutions even have an acute shortage of books and periodicals. Overall, the dramatic and continuous increase of the student population in Cameroonian higher education coupled with the lack of the corresponding policy in terms of human, financial, and physical resources is inevitably hampering the process of talent cultivation in Cameroon higher education.

\subsection{Brain Drain}

Brain-drain refers to the abandonment of a country by highly skilled professionals or highly educated individuals in favor of another country, generally following an offer of better working, learning, and living conditions (Kubler et al. 2006; Milio 2012). Brain drain can thus be viewed as a form of "high skills migration" which is the substitute of highly talented individuals who could have contributed to the development of their origin country (Afu 2016). For many years, Cameroon, like numerous African countries, has been experiencing the phenomenon of brain drain. For instance, Cameroonian emigrants were estimated to number 170,363 in 2007 in France, with 38,530 migrants, remains a preferred destination, followed by Gabon $(30,216)$, Nigeria $(16,980)$, and the United States $(12,835)$ (Afu 2016). Higher education, as said in the previous sections, is fundamental for the development of a country's human capital and the production of new or innovative knowledge. However, the ability for Cameroon higher education to fulfill this role has been continuously hampered by the incessant brain drain in which large numbers of highly skilled scholars, engineers, and students have migrated out of the country. For example, roughly 60,000 professionals especially doctors, teachers, and engineers between the period of 1985 and 1996 migrated annually at approximately 20,000 (Edokat 2000). In 2000, 17 percent of the Cameroonian population highly educated also emigrated (e.g. 42.3 percent of the 57,050 Cameroonians working in Europe are highly qualified, a good number of Ph.D. holders) (Docquier et al. 2005; Afu 2016). This phenomenon has somehow weakened the capacity of higher education institutions to massive cultivate innovative talents; brain drain is taken away a significant number of human resources that can be employed in higher education to train local skillful and creative university graduates.

\section{Strategies to Address Challenges of Talents Cultivation}

\subsection{Addressing the Problem of Massification}

5.1.1 Effective Diversification and Differentiation

According to Altbach (2017), the massification of higher education will continue around the world, as the student population will keep rising, especially in developing and middle-income countries (Altbach et al. 2017). To effectively deal with this situation, postsecondary education should become diversified and differentiated in most countries (Mohamedbhai 2008; Androsch et al. 2017). Cameroon higher education institutions may therefore get a vast array of institutions, including a clear differentiated system of institutions with clearly identified missions and purposes, which is more appropriate and relevant for innovative talents cultivation. Researchers on differentiation differentiate between horizontal and vertical differentiation within and among institutions, with horizontal differentiation driven by issues of access, and vertical by the labor market. The first relates to the student's choice of higher education institutions (Huisman 1995). The second relates to the needs of the labor market for different skills and competencies (Altbach et al. 2017). Thus, vertical differentiation should be stimulated and intensified in the Cameroonian higher education system that is still more horizontally differentiated. 
Systematic diversification is necessary for Cameroon higher education that is continuously subject to yearly growth of the student population since less differentiated systems are more vulnerable to both surges and declines in demand (Altbach et al. 2017). As such, the higher education system in Cameroon should comprise large research universities, vocationally or professional-oriented universities of applied sciences granting a range of degrees and certificates, as well as small-specialized vocational institutes providing additional qualifications. It should also include comprehensive institutions, with a broad variation in missions, focusing on whether science and technology disciplines; liberal arts subjects; vocational and professional training, or a combination of these. These can include both public and private institutions, with the common essential aim being the cultivation of innovative and entrepreneurial talents. Also, to promote excellence in innovative talents cultivation, Cameroonian should create an additional national system of differentiation by establishing and separating a new elite sector of African first-class universities, from other more national and regional-oriented comprehensive and research universities. Thus, the created universities with African first-class status should receive significant additional government support to catch up and cultivate competitive innovative talents who could compete with other talents in the international sphere.

\subsubsection{Decentralization}

Though the government has started to decentralize higher education by creating more university branches (attached centers and institutes) in different places, they need to go more further than what has been done to date to effectively meet the demands of increased enrolment leading to the critical massification of higher education (Ngwe 2016). First, the government should make sure all the regions of the country have at least one or two State universities. Second, all universities have to deploy a strategy of decentralization or the delocalization of their activities from the main campuses to departmental or sub-regional branches, which will allow the decongestion of main campuses. So, several university programs can be delocalized to such secondary or attached campuses. University's faculties, schools, and services are scattered throughout the region where the main campus is located. Moreover, decentralization should also occur at the managerial and administrative levels as important administrative tasks are still highly centralized in Cameroon (e.g. selecting, recruiting, appraising, and promoting staff) (Michaela 2012). Therefore, the government has to extend greater autonomy to individual institutions. Universities should be allowed to not only do most of their hiring, evaluation, and promotion of staff but also have their own operating budgets that they control. This will permit them to manage their staff and students more strategically, which is essential for the effectiveness of the process of innovative talents cultivation in individual universities (Mohamedbhai 2008).

5.1.3 Effective E-higher Education (E-learning and E-administration)

E-(higher) education refers to the use of information and communication technologies (ICT) in (higher) educational activities (Pavela et al. 2015). Another relevant strategy to address the problem of massification and enhance talent cultivation in Cameroon is to make e-education effective among higher education institutions through efficient e-governance practices. Implementing effective e-governance practices in higher education can ensure improved quality in terms of education and administration dissemination (Dey and Sobhan 2007), which is an essential catalyst for the cultivation of innovative and entrepreneurial talents. Cameroon is making considerable efforts in the implementation of e-governance practices in higher education. The government has launched an ambitious program called the E-National Higher Education Network Project (EHENP) that has started in 2017. The project has started with the distribution of 500,000 laptops to students from public and private universities (MINESUP 2018). The government recently built and equipped nine university digital development centers (one in each state university, one at the Inter-State Congo-Cameroon University) and one national (central) university digital development center (Brenda 2020). However, the development of e-education is still very limited among higher education institutions in Cameroon. Despite these efforts, the dissemination of e-learning and eadministration is still in a rather embryonic state. Students' access to digital terminals is still non-effective, as well as the development of the skills essential to the efficient operationalization of both physical and immaterial digital infrastructures. Besides, no strategic investment associated with e-education has been done in most private higher education institutions, apart from the distribution of laptops to students by the government. It is necessary to pursue and extend the aim to make e-higher education effective in the overall Cameroonian higher education landscape. E-learning

ICT plays a key role in the development of higher education institutions. Their use in higher education is essential for decongesting overcrowded campuses and amphitheaters. The use of ICT can also catalyze innovation, quality, and excellence, which may favor the effective cultivation of innovative and entrepreneurial talents in higher education. ICT can contribute to providing effective training to large numbers of students in African countries like Cameroon (Toure 2008), where massification is posited as an obstacle to the cultivation of innovative talents. Thus, the integration of ICT and E-learning for the decongestion of campuses and amphitheaters, and innovation and quality in Cameroon higher education should become a key priority for all involved institutions. Higher education institutions should therefore develop a holistic strategy focusing on boosting distance education. E-learning can help to reduce the number of face-to-face classes and classroom courses, thus liberating the use of some lecture 
halls (Mohamedbhai 2008). The e-learning methods can ensure more effective education and achieve quality and excellence, which is a crucial catalyst for the cultivation of innovative and entrepreneurial students. For instance, the use of virtual lectures and e-libraries and video or web conferencing, and automated library and laboratory services in the learning process is not only cost-effective but also capable to enhance the capacity of higher education institutions in the path of talent cultivation (Shrivastava et al. 2014). Therefore, all higher education institutions should be encouraged to establish operational centers or institutes for e-education to complement faceto-face education with web-based learning. Access to digital terminals should thus be made effective for students and academic staff. In this regard, the government and institutional authorities should therefore invest in the effective maximization of the bandwidth for higher education institutions. This will surely allow higher education to efficiently cultivate the critical mass of innovative and entrepreneurial individuals needed by Cameroon to move to an emerging country by 2035.

E-administration

The implementation of e-learning in higher education needs to be accompanied by effective e-administration, in the absence of which it may be difficult to ensure its sustainability. In the process of talent cultivation, higher education also needs to render its administrative activities more effective and e-administration is an essential strategy to limit any administrative shortcomings (Shrivastava et al. 2014). The use of ICT in higher education administration can ensure improved information, cost-effective and easy-to-access service delivery while empowering faculties, encouraging students and academic staff participation in the decision-making processes, and enhancing the efficiency of higher education institutions. The implementation of e-administration in higher education can as well increase transparency and effectiveness in the functioning of higher education institutions (Alhomod and Shafi 2012). Also, the differentiation and diversification of higher education will remarkably increase the number of higher education institutions and branches. The government needs to keep tracking of the functioning of all these institutions and branches. E-administration ensures the expansion of universities and colleges while allowing their effective management by empowering higher education leaders and managers to manage the progress of the education plan and vision effectively national wide (Shrivastava et al. 2014). If the quality of the higher education system in Cameroon has to be improved for the sustainable cultivation of innovative and entrepreneurial talents, there is no alternative to e-learning coupled with e-administration. E-administration in higher education institutions will ensure their effective and real-time monitoring by all governing authorities (the government and regulatory bodies) including different stakeholders, students, and the society for quality enhancement and sustainability (Alhomod and Shafi 2012; Shrivastava et al. 2014).

Necessity of Training

The implementation of e-higher education (e-learning and e-administration) in Cameroon will depend on the training of various stakeholders to be effective. Access to ICT by students, faculty, and administrators is not enough to effectively achieve the target goal, producing innovative and entrepreneurial talents. Most (higher) education stakeholders, especially faculty and administrators, lack ITC, e-learning, and e-administration skills to effectively involve in e-higher education (Mbangwana 2008). The development of the skills essential to the efficient operationalization of existing and future physical and immaterial digital infrastructures should be implemented for the successful digital transformation of Cameroonian higher education. The success of any eeducation policy relies on the availability of ICT expertise among higher education institutions in the nation. Thus, training opportunities should be provided to higher education stakeholders to achieve the cultivation of highly skilled talents from the benefits of e-education (Mbangwana 2008; Fonkoua 2006).

\subsection{Addressing the Problem of Shortage of Funds}

\subsubsection{Marketization}

Like in many other African countries, because of its inability to continue providing increased public funding to higher education institutions, especially with increasing enrolments, the Cameroonian government has introduced cost-sharing measures charging their students' tuition fees (Ngwe 2016). Financial aid programs or student loan schemes have accompanied the introduction of such fees on equity grounds for needy students. However, these measures have proved to be less effective and have been difficult to sustain because they are generally financially unsustainable. As such, the problem of shortage of funds remains unsolved in higher education institutions. To generate their funds to complement government funding, tertiary education institutions can involve in the promotion of marketization by developing market-driven activities without shifting away from their main mission which is the cultivation of innovative talents (by preserving quality and excellence). Marketization can be described as the attempt to put the provision of higher education on a market basis, where the demand and supply of student education, academic research, and other university activities are balanced through the price mechanism (Brown 2015). There are three major dimensions of marketization that can be developed for establishing and supporting higher education institutions in Africa, in general, and in Cameroon, in particular: the market for the service of education, the market for research, and entrepreneurialism.

The first market that the universities can explore is the market for the services in providing education (Zhang 
2017). One of the approaches that can significantly improve the funding of higher education in terms of education marketization is the running of parallel programs (Geiger 2009). By the way, Cameroonian higher education institutions can run separate programs for which they charge full economic cost fees for those students who are unable to gain access to higher education by the normal admission process and criteria but have the financial resources to attend higher learning (Palfreyman and Tapper 2016). These programs will therefore be run in parallel to the institution's ordinary programs. Another approach is to expand the market of higher education to the needs of adults by offering them special courses aside from the institutional regular courses. Cameroonian higher education institutions should seek to serve working adult learners who wish to acquire a particular set of knowledge and skills rather than an academic degree (e.g. job-related knowledge and skills), which may be a good source of funding (Brown 2015). To respond to the needs of potential adult students, higher education institutions can design various modules containing a set of skill-based courses with well-defined knowledge according to the market demand (Molesworth et al. 2011). The use of e-learning can be a low-cost means, but a powerful instrument in this respect, since such adult learners may need to take courses in a time and location that suit their schedule.

The second market that Cameroonian higher education institutions can strongly rely on for their funding is the market for newly created knowledge. This method has successfully been employed for the effective cultivation of innovative talents in reference countries like the United States, the United Kingdom, Germany, China, France, Japan, Russia, Australia, etc. (Brown 2015). This mainly concerns the University-Industry Link. This deals with the marketing of the results of higher education research. Many universities worldwide undertake basic research based on academic logic, while the industries apply basic research to commercial purposes (Hewitt-Dundas and Roper 2016). The Cameroonian government developed a strategic policy based on the principles of intellectual property, to encourage cooperation between the academics in universities and business firms but this governmental policy is still less effective among higher education institutions. Yet, many companies around the country need scientific data and results for their performance but do not have the abilities and time to carry out research. The opportunities opened through such practices create an atmosphere among academic researchers to respond to the needs in the social market (Dbis 2009). Cameroonian higher education institutions can also sign contracts with companies whereby companies provide them with funding in exchange for research activities and results. Contract research is practiced in many Western and Asian universities where they sell the resulting knowledge (future knowledge) to industries in the form of licensing fees (Deem 2001; Dbis 2009). Thus, higher education institutions in Cameroon can certainly solve the problem of shortage of funds following such examples.

Moreover, Higher education institutions should engage in entrepreneurial activities as entrepreneurship the Cameroonian government has encouraged them to do since the beginning of the 2000s (Michaela 2012; Ngwe 2016). In fact, entrepreneurship in higher education will not just allow postsecondary education institutions to meet their funding needs (Clark 1998). It will primarily foster the cultivation of innovative talents in such institutions. Moreover, an entrepreneurial higher education will certainly contribute to the country's economic and social development. Therefore, institutions' managers should provide opportunities within the higher education institutions for staff and students to engage in entrepreneurial experiences. This can result in the creation of university factories based for instance on the technical, professional specialties promoted by the intuitions' programs (Deem 2001).

\subsection{Addressing the Problem of Brain Drain}

\subsubsection{Brain Gain Policies}

In the previous section 4.3 , the term brain drain referred to skilled professionals who leave their source countries to seek better promising opportunities elsewhere (Zhang 2001). Then, brain gain can be defined as the movement whereby highly skilled individuals who left their origin countries to seek more promising opportunities elsewhere decide to come back and participate in the building and the development of their native countries (Ying 2005). Due to globalization and internationalization, the mobility of Cameroonian students and scholars has greatly increased (Docquier et al. 2005). Thus, Cameroon has lost many of its talents who could efficiently help in the process of innovative talents cultivation locally (see section 4.3). Docquier and Rapoport (2006) consider members of diasporas as key assets for the building of human capital in source countries if effective policies are implemented in this regard by their countries of origin (Docquier and Rapoport 2006). Drained skilled immigrants could therefore be beneficial for national growth and development through participation in the cultivation of local innovative and entrepreneurial talents. Empirical research reveals that this is indeed the case for many developing countries (Docquier and Rapoport 2006). Cameroon should indeed learn from such experiences and implement effective policies to engage the Cameroonian diaspora in the enterprise of innovative and entrepreneurial talent cultivation, which will be largely beneficial for the country's social and economic development. Therefore, Cameroon has to implement effective and efficient policies to cooperate with the overseas Cameroonians who actually should play an important role in the process of modernization, generally and the development of the Cameroonian higher education system, particularly. Batista et al. (2007) suggest that, by implementing effective cooperation with the diaspora and encouraging them to participate in national development, there may be 
substantial human capital gains locally, in terms of local innovative and entrepreneurial talent cultivation (Batista et al. 2007). They are considerable channels for technological transfers and other exchanges (Bloomfield et al. 2018). According to Ying (2005), diaspora comprises individuals who are also better researchers and fundraisers. Indeed, members of the diaspora possess valuable "transnational skills", including a better understanding of foreign science and research, broader research agendas due to familiarity with foreign research methods, a greater facility with foreign equipment, better foreign language skills, a stronger ability to adopt new research directions and a greater ability to develop international cooperation (Ying 2005). Therefore, the value of the Cameroonian overseas is evidently of great importance and essential for the cultivation of innovative talents in Cameroon.

\section{Conclusion}

This paper examined the issue of innovative talents cultivation in the Cameroonian higher education system in Sub-Saharan Africa. The paper reveals that the active and effective cultivation of innovative and entrepreneurial talents by higher education is essential for the socio-economic emergence and development of countries like Cameroon. The efforts made by the Cameroonian government to curb unemployment and achieve national growth and development shortly may be successful if the country's higher education institutions effectively engage in the enterprise of innovative and entrepreneurial talent cultivation. Though higher education leaders are willing to lead higher education institutions to realize this mission, they are facing serious difficulties that seem to jeopardize their efforts to train skillful and creative graduates. Such difficulties are mainly related to the rampant massification of higher education, shortage of financial resources, and brain drain. While encouraging the promotion of the cultivation of innovative and entrepreneurial talents in higher education to boost national development, this paper suggests some relevant strategies to address existing challenges and enhance the capacity of Cameroonian higher education institutions in terms of talent cultivation. By implementing effective differentiation, diversification, and decentralization of higher education, effective e-higher education, marketization, and brain gain policies, such challenges could easily be curbed and the cultivation of innovative and entrepreneurial talents made more effective. Suggested future researches may include reforming higher education curricula, developing effective models for innovative and entrepreneurial talent cultivation in Cameroon, designing development programs to equip higher education stakeholders for effective talent cultivation, exploring concrete strategic actions that the Cameroonian diaspora can undertake to serve their source country in the process of talent cultivation, and duplicating this study in field-based research.

\section{References}

Afu, I. A. (2016). The Impact of Migration and Brain Drain in Cameroon. Tallinn: Master's Thesis, Tallinn University of Technology.

Alhomod, S. M. \& Shafi, M. M. (2012). E-Governance in Education: Reasons for introduction and Impact. International Journal of Scientific \& Engineering Research, 3 (2), 1-5.

Altbach, P. G. (2017). Responding to Massification Differentiation in Postsecondary Education Worldwide. Rotterdam: Sense Publishers.

Amin, A. et al. (2005). Economic Analysis of Private Returns to Investment in Education in Cameroon. Regional Conference on Education in West Africa: Constraints and Opportunities (pp. 1-16). Dakar: African Institute for Economic Development and Planning (IDEP).

Androsch, H. et al. (2017). Prospects and Future Tasks of Universities: Digitalization, Internationalization, and Differentiation. Zürich: LIT VERLAG GmbH \& Co. KG Wien, Zweigniederlassung.

Ansu, Y. et al. (2012). In "Good Growth and Governance in Africa: Rethinking Development Strategies” by Noman, Akbar, Kwesi Botchwey, Howard Stein, and Joseph E. Stiglitz. Oxford Scholarship.

Batista C., Lacuesta, A. \& Vicente, P. C. (2007). Brain Drain or Brain Gain? Micro Evidence from an African Success Story. Discussion Paper No. 3035 September 2007, Institute for the Study of Labor (IZA), Bonn.

Bella, A. E. (2010). L'Institution Universitaire au Cameroun: Dynamiques, Ruptures et Permanences d'une Réalité Plurielle; des Origines à 2001. Yaoundé, Cameroun: Sciences de l'Homme et Société, Université de Yaoundé1.

Bilola, T. et al. (2016). Professionalization for Graduate Employability in Cameroon Higher Education: Old Wine in New Wineskins? The Modern Higher Education Review, 1, 120-133.

Bloomfield, A., Rose, B. A., Preston, A. M., \& Henneberger, A. K. (2018). Brain Drain in Maryland: Exploring Student Movement from High School to Postsecondary Education and the Workforce. Baltimore: MD: Maryland Longitudinal Data System Center.

Brenda. (2020). Higher Education: Classes Effectively Begin Today. Cameroon Tribune. [Online] Available at: https://www.cameroon-tribune.cm/article.html/35768/en.html/higher-education-classes-effectively\# (November 17, 2020).

Brown, R. (2015). The marketization of Higher Education: Issues and Ironies. Liverpool: Liverpool Hope University. 
Cameroon Youths and Students Forum for Peace. (2014). Voice of Youth on Education Sector Reform for Youth Employment. Yaounde: Friedrich Ebert Stiftung, FES Cameroon.

Changli, Y. et al. (2009). On the Cultivation of Innovative Talents in Colleges and Universities. International Education Studies, 2 (4), 162-167.

Dbis. (2009). Higher Ambitions; the future of universities in a knowledge economy. London: Department of Business, Industry and Skills.

Deem, R. (2001). 'Globalization, New Managerialism, Academic Capitalism and Entrepreneurialism in Universities. Is the Local Dimension Still Important?' Comparative Education, 37(1), 7-20.

Dey, S. K. \& Sobhan, M. A. (2007). Practicing E-Governance in Higher Education Institutions to Enhance Quality of Education, 1-12. [Online] Available at: https://www.researchgate.net/publication/254410211 (November 17, 2020)

Docquier, F. et al. (2005). International Migration by Educational Attainment. [Online] Available at: https://www.researchgate.net/publication/228739789_International_Migration_by_Educational_Attainment 1990-2000-Release 11 (November 17, 2020).

Docquier, F. \& Rapoport, $\bar{H}$. (2006). The Brain Drain. A New Entry for the New Palgrave Dictionary of Economics (second edition), 1-8.

Edokat, T. 2000. Effects of brain drain on higher education in Cameroon. In Tapsoba, S.J.M., Kassoum, S., Houenou, P.V., One, B., Sethi, M. and Ngu, J. (eds), Brain Drain and Capacity Building in Africa. Joint publication of the Economic Commission for Africa, the International Development Research Centre, and the International Organization for Migration, Dakar: 174-183.

Ekane, D. (2010). The Context of an Urban Social Problem in Cameroon: Case Study of Youth Unemployment. Stockholm: Master's thesis, Stockholm University.

Elias, P. et al. (2004). Is Mass Higher Education Working? Evidence from the Labour Market Experiences of Recent Graduates. National Institute Economic Review, 190(1), 60- 74.

Fonkoua, P. (2006). Approche Conceptuelle de la « Ticelogie » ou Science de l'Intégration des TIC dans la Formation des Formateurs. Dans P. F. (Dir.), Intégration des Tic dans le Processus Enseignementapprentissage au Cameroun. Yaounde, Cameroon: ROCARE-Cameroon: 223-234.

Fouda, N. M. et al. (2012). Les Reformes de Gouvernance dans l'Enseignement Supérieur Camerounais. Réformes de Gouvernance dans l'Enseignement Supérieur: Quelles Politiques Avec Quelles Effets. Dakar: UNESCO: $1-61$.

Geo-JaJa, M. et al. (2001). Structural Adjustment as an Inadvertent Enemy of Human Development in Africa. Journal of Black Studies, 32(1), 30-49.

Hewitt-Dundas, N. \& Roper, S. (2016). The Marketization of Higher Education: A Causal Analysis of Innovation in UK Universities. ERC Research Paper, 39.

Huisman, J. (1995). Differentiation, Diversity and Dependency in Higher Education. Twente: Lemma/CHEPS.

ILO. (1983). Resolution Concerning Economically Active Population, Employment, Unemployment and Underemployment. Geneva: Bulletin of Labor Statistics, 1983-3.

ILO. (2017). World Employment and Social Outlook: Trends 2017. Geneva: International Labor Office.

Lahaye, L. et al. (2013). Technical Evaluation Report of the Strategy Document of the Education and Training Sector (2013-2020) in View of its Endorsement to the Global Partnership for Education by the Technical and Financial Partners. Cameroon: Republic of Cameroon, Final Report.

Mbah, M. (2014). The Dilemma of Graduate Unemployment within a Context of Poverty, Scarcity and Fragile Economy: Are There Lessons for the University? International Journal of Economics and Finance, 6(12), 27-36.

Mbangwana, M.A. (2008). Introduction of ICT in Schools and Classrooms in Cameroon. Dans T. T. In K. Toure, ICT and Changing Mindsets in Education in Bamenda. ERNWACA/ROCARE, Cameroon: Langaa; Bamako, Mali: 123-134.

Michaela, M. (2012). Étude des Réformes Conduites au : Burkina Faso, Cameroun, Maroc et Sénégal. La Gouvernance dans l'Enseignement Supérieur : Quelles Politiques avec Quels Effets ? Paris: UNESCO.

Milio, S. (2012). Brain Drain, Brain Exchange and Brain Circulation: The Case of Italy Viewed from a Global Perspective. Rome: Aspen Institute Italia.

MINEPAT. (2009). Cameroun Vision 2035. Yaounde: Ministère de l'Economie, de la Planification et de l'Aménagement du Territoire.

MINESUP. (1993). Decree No. 93/026 of 19 January 1993 Creating State Universities in Cameroon. Yaounde, Cameroon: Ministry of Higher Education.

MINESUP. (1993). Decree No. 93/027 of 19 January 1993 Providing Common Guidelines on the Operations of the State Universities in Cameroon. Yaounde, Cameroon: Ministry of Higher Education.

MINESUP. (2001). Law No. 005 of 16 April 2001 on the Orientation of Higher Education. Yaounde, Cameroon: Ministry of Higher Education. 
MINESUP. (2003, 2004, 2005, 2006, 2007, 2008, 2009, 2011,2012). Annuaires statistiques de l'Enseignement Supérieur-Editions 2003, 2004, 2005, 2006, 2007, 2008, 2009, 2011 et 2012. Yaounde, Cameroon: The Ministry of Higher Education.

MINESUP. (2014). L’Enseignement Supérieur au Cameroun: Cartographie 2014 des Institutions. Yaounde, Cameroon: The Ministry of Higher Education.

MINESUP. (2014). Répertoire des Institutions Privées d'Enseignement Supérieur, DDES. Yaoundé, Cameroun: Publication du Ministère de l'Enseignement Supérieur.

MINESUP. (2018). Technical Data Sheet for the Project of E-National Higher Education Network. Yaounde, Cameroon: Ministry of Higher Education.

MINESUP. (2020). Les Chiffres Clés de l'Enseignement Supérieur au Cameroun. Yaounde, Cameroon: Ministry of Higher Education.

Miralles P. (2007). Le Management des Talents. Paris: L'Harmattan.

Molesworth, M., Scullion, R. \& Nixon, E. (2011). The Marketization of Higher Education and the Student as Consumer. 2 Park Square, Milton Park, Abingdon, Oxon: Routledge.

Mohamedbhai, G. (2008). The effects of Massification on higher education in Africa. Accra, Ghana: Association of African Universities.

Neneh, B. (2014). An Assessment of Entrepreneurial Intention among University Students in Cameroon. Mediterranean Journal of Social Sciences.

Ngwe, L. (2016). D’un Système Voué à la Construction de l'Etat au Projet d'un Modèle Entrepreneurial de Developpement: La Métamorphose de l'Enseignement Supérieur au Cameroun. Dans L. E. Ngwe, L'Enseignement Supérieur au Cameroun Depuis la Réforme de 1993: Dynamiques et Perspectives. Dakar: CODESRIA : 16-28.

NIS. (2015). Annuaire Statistique du Cameroun. Yaoundé, Cameroun: National Institute of Statistics.

NIS. (2017). Annuaire Statistique du Cameroun. Yaounde, Cameroon: National Institute of Statistics.

Njeuma, D.L. et al. (1999). Reforming a National System of Higher Education: The Case of Cameroon. Washington: ADEA Working Group on Higher Education, the World Bank.

Ntemngweh, P. (2016). Education-Job Mismatch among University Graduates in Cameroon: The Perspectives of Graduates in the Field of Humanities. Oslo: Master Thesis, University of Oslo.

Oyelere, R. U. (2007). Brain Drain, Waste or Gain? What We Know about the Kenyan Case. Atlanta Georgia: Georgia Institute of Technology.

Palfreyman, D. \& Tapper, T. (2016). The Marketization of English Higher Education and the Financing of Tuition Fees. Sociology-London Review of Education, 14, 47-55. https://doi.org/10.18546//re.14.1.06.

Pavela, A.P. et al. (2015). ICT and E-Learning - Catalysts for Innovation and Quality in Higher Education. Second Global Conference on Business, Economics, Management and Tourism, 30-31 October 2014. Prague, Czech Republic: 704-711.

Peretti J.-M. . (2009). Tous Talentueux. Paris: Eyrolles.

Republic of Cameroon. (2015). Fostering Skills for Inclusive Workforce Development, Competitiveness, and Growth: A Framework for Action. Yaounde: World Bank.

Shrivastava, R. K. Raizada, A.K. \& Saxena, N. (2014). Role of E-Governance to Strengthen Higher Education System in India. IOSR Journal of Research \& Method in Education (IOSR-JRME), 4 (2), 57-62.

Tchombe, M. T. (1999). Structural Reforms in Education in Cameroon. Cameroon.

Teneng, P., P. (2016). Skills Oriented Higher Education and Graduate Employability in Cameroon: The Case of the National Employment Fund. International Journal of New Technology and Research, 2(5), 26-29.

Toure, K. (2008). Introduction: ICT and Changing Mindsets in Education. Dans K. T. Toure, ICT and Changing Mindsets in Education. ERNWACA / ROCARE B, Cameroon: Langaa; Bamako, Mali: 7-12.

Ulrich D.et al. (2012). « What is Talent? ». Leader-to-Leader, 55-61.

UNESCO. (2000). Education for All. Paris: UNESCO.

UNESCO Institute for Statistics (UIS). (2013). Trends in Tertiary Education: Sub-Saharan Africa. Montreal, Canada: UIS

Wu, Z. W. \& Zhu, L. R. (2017). Cultivating Innovative and Entrepreneurial Talent in the Higher Vocational Automotive Major with the "On-board Educational Factory" Model. EURASIA Journal of Mathematics Science and Technology Education, 13(7), 2993-3000. DOI 10.12973/eurasia.2017.00746a.

Yang, C. (2005). The Basic Quality Needed by Innovative Talents. Search.2.

Ying, L. (2005). Brain Drain and Brain Gain in China since 1978: The Impact of Internationalization and Globalization. Oslo: Master Thesis, University of Oslo.

Zhang, D. (2014). Study and Improvement on the Competence Model of Talents with Entrepreneurial Skills in Colleges and Universities in the Process of Industrialization. BioTechnology, 11186-11193.

Zhang, T. (2017). The Marketization of Higher Education Discourse: A Genre Analysis of University Website Homepages in China. Higher Education Studies, 7(3), 64-79. http://doi.org/10.5539/hes.v7n3p64. 
Zhang, Z. (2017). Gifted Education in China. Educational Psychology \& Counselling, 1-12, https://doi.org/10.1080/2331186X.2017.1364881.

Zweig, D. et al. (2008). Redefining the Brain Drain: China's Diaspora Option. Hong Kong: The Hong Kong University of Science and Technology. 